
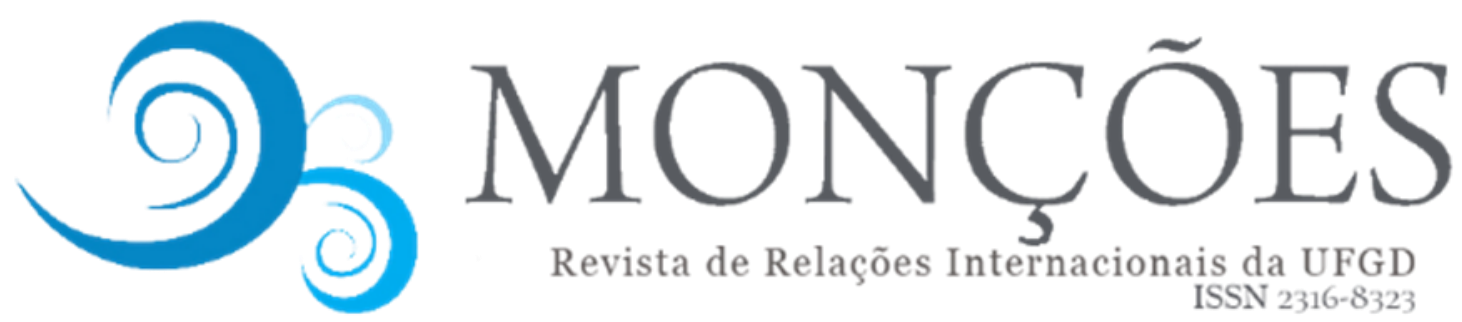

Revista de Relações Internacionais da UFGD

ISSN 2316-8323

\title{
HIDRELÉTRICAS, DIREITOS HUMANOS E ALIENAÇÃO DO TERRITÓRIO NA AMAZÔNIA: ESTUDO DE CASO DA UHE TABAJARA - RONDÔNIA ${ }^{1}$
}

\author{
RICARDO GILSON DA COSTA SILVA \\ Professor da Universidade Federal de Rondônia (UNIR), Porto Velho (RO), Brasil \\ ORCID: https://orcid.org/0000-0002-3348-9629 \\ rgilson@unir.br
}

\begin{abstract}
GISELE DIAS DE OLIVEIRA BLEGGI CUNHA
Procuradora da República (MPF/RO), Mestranda em Direitos Humanos e Desenvolvimento da Justiça pela Universidade Federal de Rondônia (DHJUS/UNIR), Porto Velho (RO), Brasil

ORCID: https://orcid.org/0000-0001-7399-9423

giselebleggi@mpf.mp.br
\end{abstract}

REBECA CAMPOS FERREIRA

Perita em Antropologia do Ministério Público Federal (MPF), Doutoranda em Antropologia

Social pela Universidade de São Paulo (USP), Porto Velho (RO), Brasil

ORCID: https://orcid.org/0000-0002-6401-3199

rebeca.ferreira@usp.br

\begin{abstract}
Resumo: Os megaprojetos hidrelétricos na Amazônia brasileira provocam grandes impactos socioambientais e violações sistemáticas dos Direitos Humanos dos povos indígenas e comunidades tradicionais. As inúmeras barragens construídas apresentam um histórico de fragmentação de territórios tradicionais e de exclusão social. Neste texto, analisa-se mais um desses projetos, que está em formulação, a Hidrelétrica Tabajara. Assim, problematiza-se planejamento hidrelétrico na Amazônia articulado ao que se qualifica de alienação do território. Posteriormente, a análise se desdobra no uso corporativo do território para o capital e na alienação do território para os grupos sociais afetados, atingindo os direitos humanos e os modos de vida das comunidades afetadas. Conclui-se que os grandes projetos na região instituem escalas de domínio político dos recursos naturais e dos territórios, de modo que se ressalta o uso corporativo do espaço regional na escala do capital e do Estado, ao passo que, igualmente, tem-se a alienação dos territórios dos grupos sociais mais vulneráveis, no qual o sentido e destino do lugar fica afetado pelas lógicas do capital hidrelétrico, constituindo-se em formas de dominação e expropriação social.
\end{abstract}

Palavras-chave: Amazônia; Comunidades Tradicionais; Direitos Humanos; Espaço Agrário.

\section{HYDROELECTRIC POWER PLANTS, HUMANS RIGHTS AND ALIENATION OF THE TERRITORY IN THE BRAZILIAN AMAZON: THE CASE STUDY OF UHE TABAJARA - RONDÔNIA}

\footnotetext{
${ }^{1}$ A pesquisa contou com apoio das instituições: DHJUS/EMERON/UNIR e FAPERO.
} 
Abstract: The hydroelectric megaprojects in the Brazilian Amazon cause major socio-environmental impacts and systematic violations of the Human Rights of indigenous peoples and traditional communities. The numerous dams built have a historical of fragmentation of traditional territories and social exclusion. In this text, one more of these projects is analyzed, which is being formulated, the Tabajara Hydroelectric Power Plant. Thus, this study problematizes the hydroelectric planning in the Brazilian Amazon, linked to what qualifies as alienation of the territory. Posteriorly, the analysis unfolds in the corporate use of the territory for capital and in the alienation of the territory for the affected social groups, reaching the human rights and the ways of life of the affected communities. It is concluded that the great projects in the region establish scales of political dominance over natural resources and territories, so that the corporate use of regional space at the scale of capital and state is emphasized, while, equally, there is the alienation of the territories of the most vulnerable social groups, in which the sense and destination of the place is affected by the logic of hydroelectric capital, constituting forms of domination and social expropriation.

Keywords: Brazilian Amazon. Tradicional Comunities. Humans Rights.

\section{HIDROELÉCTRICA, DERECHOS HUMANOS Y ALIENACIÓN DEL TERRITORIO EN LA AMAZONÍA: ESTUDIO DE CASO DE UHE TABAJARA - RONDÔNIA}

Resumen: Los megaproyectos hidroeléctricos en la Amazonia brasileña provocan grandes impactos socioambientales y violaciones sistemáticas de los derechos humanos de los pueblos indígenas y las comunidades tradicionales. Las numerosas presas construidas tienen un historial de fragmentación de los territorios tradicionales y de exclusión social. En este texto se analiza uno más de estos proyectos, que está en fase de formulación: la Central Hidroeléctrica de Tabajara. Así, se problematiza la planificación hidroeléctrica en la Amazonía, articulada a lo que se califica como alienación del territorio. Posteriormente, el análisis se despliega en el uso corporativo del territorio para el capital y la enajenación del territorio a los grupos sociales afectados, alcanzando los derechos humanos y las formas de vida de las comunidades afectadas. Se concluye que los grandes proyectos en la región establecen escalas de dominación política de los recursos naturales y de los territorios, por lo que se acentúa el uso corporativo del espacio regional en la escala del capital y del Estado, a la vez que se observa la enajenación de los territorios de los grupos sociales más vulnerables, en los que la dirección y el destino del lugar se ven afectados por las lógicas del capital hidroeléctrico, constituyendo formas de dominación y expropiación social.

Palabras clave: Amazonía; comunidades tradicionales; derechos humanos; espacio agrario.

\section{Introdução}

Os megaprojetos hidrelétricos na Amazônia brasileira provocam grandes impactos socioambientais e violações sistemáticas dos Direitos Humanos dos povos indígenas e comunidades tradicionais. As inúmeras barragens construídas apresentam um histórico de fragmentação de territórios tradicionais, dos lugares objeto de intervenção (cidades, vilas, comunidades), e exclusão social, com os benefícios decorrentes da atividade de geração de energia, sendo concentrados em locais muito distantes daqueles onde os impactos territoriais são mais severamente sofridos.

As promessas de desenvolvimento local, geração de empregos e melhoria das condições de vida da população próxima das barragens são costumeiramente 
quebradas em todos os megaprojetos da região amazônica, e o resultado da atividade revela-se devastador, com inúmeras famílias desassistidas e não reparadas integralmente pelos danos sofridos, resultando em enorme dívida social, a exemplo das recentes construções das UHE's de Jirau e Santo Antônio (Rondônia) e Belo Monte (Pará).

Neste contexto, a partir da proposta de construção de mais uma hidrelétrica na Amazônia - a Hidrelétrica de Tabajara, localizada no município de Machadinho D'Oeste, norte do estado de Rondônia -, problematiza-se as transformações sociogeográficas na escala local, centralizando a análise na crítica do planejamento hidrelétrico na região amazônica (segunda seção do texto), que se desdobra em dois processos articulados, qualificado como uso corporativo do território para o capital (terceira seção) e, consequente, alienação do território para os grupos sociais afetados (quarta seção), o que implica ampliar a análise à questão dos direitos humanos e modos de vida da localidade de Tabajara (quinta seção). Quanto aos procedimentos metodológicos, adotou-se; i) revisão bibliográfica, priorizando os estudos regionais de grandes projetos e seus impactos sociogeográficos, articulando o debate teórico com estudos empíricos na Amazônia; ii) análise documental do Estudo de Impacto Ambiental/Relatório de Impacto Ambiental do projeto hidrelétrico e análise do Laudo Pericial elaborado pelo Ministério Público Federal de Rondônia (FERREIRA, 2017); iii) sistematização dos dados socioeconômicos e territoriais da área de estudo e trabalho de campo, com observação direta na Área de Influência Direta.

Por fim, conclui-se que os grandes projetos hidrelétricos na região instituem escalas de domínios dos recursos da natureza e de pressões políticas nos territórios tradicionais, de modo a produzir a alienação do território com a internalização ou territorialização das lógicas do capital hidrelétrico, ampliando as desigualdades socioespaciais na Amazônia. Ressalta-se que o estado atual do projeto hidrelétrico se encontra em revisão dos estudos de impacto ambiental, dadas as inconsistências apresentadas na primeira versão do documento técnico (BRASIL, 2020). Contudo, ainda que seja um projeto em potência, que a depender da conjuntura política e econômica pode ser posto em construção, há toda uma psicoesfera (SANTOS, 1996) do capital hidrelétrico que povoa a região, antecedendo e anunciando as transformações vindouras na cidade e no campo, no qual as possíveis 
desterritorializações das comunidades tradicionais tendem a reproduzir na escala local a universalidade das expropriações do capital na Amazônia.

\section{Grandes obras, sistema de engenharia e alienação do território}

As pesquisas referentes às grandes obras de infraestruturas na Amazônia, no campo das ciências humanas, analisaram os impactos sociais, econômicos, culturais, ambientais e territoriais que essas ações acarretaram aos lugares em que se instalaram (ALMEIDA, 2009; CASTRO, 2012; FEARNSIDE, 2015). Desde vilas, povoados, comunidades, cidades e região, o alcance espacial desses projetos abrangem um amplo conjunto de problemas sociais que continuam a se materializar, substancialmente, nos espaços geográficos objeto dessas ações políticas (MAB, 2004; SCABIN et.al. 2015; CAVALCANTE et. al, 2011; LIMA, 2020).

Em geral, os recursos analíticos acionados para o entendimento socioespacial dessas obras - mineração, hidrelétricas, hidrovias, rodovias, portos, agronegócios foram expressos nos conceitos de grandes projetos, megaprojetos, megaempreendimentos, grandes obras e sistemas de engenharia, que denotaram a territorialização do capital, sempre com apoio financeiro, coordenação política e regulação jurídica do Estado, no sentido de ampliar a exploração da natureza no processo de acumulação, reprodução ampliada e expansão geográfica do capital na hileia amazônica (CASTRO, 2012; LIMA \& COSTA SILVA, 2018; CASTILHO, 2019).

Esses grandes sistemas de engenharias (SANTOS, 1996) constituem a moderna materialidade técnica do espaço que produz a fluidez do território, ampliando a escala da relação social, ou seja, a multiescalaridade do local. De tal modo, essas infraestruturas podem ser vistas como malhas do poder instituído na apropriação mercantil da natureza e de territórios tradicionais em toda a região amazônica, todas elas resultando em relações políticas evidentemente assimétricas, o que significa sempre algum grau de controle político do território pelo ator hegemônico - Estado e capital - a partir da natureza metabolizada em mercadoria. Um novo sistema de engenharia, representado pelos megaprojetos, institui nos lugares e nos territórios o tempo do capital, que é sempre um tempo multiescalar que impõem a esses espaços lógicas socioeconômicas exógenas, resultando em estranhamentos, conflitos e alienação. Queremos acrescentar e problematizar mais um processo social decorrente, o que estamos qualificando de alienação do território. 
O conceito de alienação, desenvolvido por Marx nos Manuscritos Econômico-

Filosóficos de 1844, dispõe sobre a condição do sujeito que perde autonomia frente ao produto do seu trabalho, de modo que este - o produto do trabalho - se mostra estranho ao sujeito que o produziu. Trata-se de um processo histórico em que o sujeito (o trabalhador), na esfera das relações capitalistas de produção, submerge a consciência criadora de seu trabalho, abstraindo de seu reconhecimento sua capacidade inventiva laboral. O trabalho apresenta dupla dimensão, sendo trabalho consciente - realização das potencialidades humanas - e trabalho alienado submetido às necessidades do capital -, donde o trabalho é uma mercadoria. Segundo Marx:

A alienação do trabalhador no seu produto significa não só que o trabalho se transforma em objeto, assume uma existência externa, mas que existe independentemente, fora dele e a ele estranho, e se torna um poder autónomo em oposição com ele; que a vida que se deu ao objecto se torna uma força hostil e antagónica (MARX, 1993, p. 160).

A exteriorização do trabalho, fruto das relações sociais de classe, representa um deslocamento da consciência do sujeito objetivada em sua ação, um ato não reconhecido, um estranhamento. Marx entende a alienação, no mundo do trabalho, como processos articulados de exteriorização da essência humana, relações sociais do ser humano evidenciadas: i) em relação ao produto do trabalho; ii) no processo de produção; iii) em relação à existência do indivíduo enquanto membro do gênero humano; e iv) em relação aos outros indivíduos no processo social. Na primeira situação, trata-se do não reconhecimento da capacidade criativa no produto produzido, a alienação em face ao produto do trabalho. Em seguida, tem-se a alienação ativa, ou seja, a produção efetiva da alienação no processo produtivo, um trabalho forçado, contraditório à consciência criativa. Quanto ao gênero humano em seu mundo social, a alienação refere-se à individualização do sujeito distanciado da coletividade humana, do ser social multidimensional. Por fim, a exteriorização alcança um grau intenso de individualização e desenraizamento do grupo social, momento em que não há reconhecimento e pertencimento por parte do sujeito em relação aos indivíduos do grupo social, daí a insensibilidade, o egoísmo e a falta de solidariedade para com o ser humano próximo, em suas necessidades sociais mais básicas.

Mészáros (2006, p. 14) sistematiza a alienação em Marx como controle do metabolismo social pelo capital e, a exemplo dos processos acima descritos, indica 
os significados desse processo quanto: "1) [à] alienação dos seres humanos em relação à natureza; 2) à sua própria atividade produtiva; 3) à sua espécie, como espécie humana; e 4) de uns em relação aos outros" (itálico do autor). A alienação do trabalho encontra em Franco (2011, p. 118) sua relação como despertencimento social e desenraizamento em relação à natureza. Particularmente à natureza, no mundo do trabalho, há a afirmação do tempo do capital que ignora e submerge o tempo da natureza, de modo a comprometer, segundo a autora, os limites biopsicossociais de defesa da vida humana. Tal processo se consolida na ruptura da razão social do trabalho para com a natureza, o meio geográfico que envolve e condiciona a sociedade no processo socioespacial, de modo que o processo de "desenraizamento em relação à Natureza se evidencia, também, na contradição entre os tempos sociais do capital e os ciclos e sistemas reguladores biológicos" (itálico da autora), reforçado que a alienação do mundo do trabalho é também uma alienação do sujeito em relação à natureza. De modo geral, o entendimento da alienação no pensamento marxista remete às condições sociais históricas em que "um indivíduo, um grupo, uma instituição ou uma sociedade se tornam (ou permanecem) alheios, estranhos, enfim, alienados [...] aos resultados ou produtos de sua própria atividade (e à atividade ela mesma), e/ou [...] à natureza na qual vivem" (BOTTOMORE, 2001, p. 5).

A separação do sujeito social em relação à natureza, ao meio geográfico indissociável do trabalho e à existência humana, permite-nos transpor tal processo à alienação do território. A ação do capital quando da extração intensiva de recursos da natureza exige, por seu turno, a modificação técnica do espaço, o que significa que os sistemas de engenharias - os objetos técnicos - servem tanto à exploração produtiva direta, quanto à aceleração do tempo social imposto pelos agentes hegemônicos. Assim, tem-se o tempo do capital territorializado e tendendo a ser hegemônico no tempo social da sociedade local. Essa dissociação aparece quando há perspectivas diferentes e antagônicas de prática e concepção de território.

Tais diferenças já havia sido problematizado por Jean Gottmann (1975), em sua contribuição à teoria social do território, quando propusera que esta categoria poderia apresentar tanto a condição de recurso quanto a de morada, ressaltando que tais dimensões sociopolíticas poderiam emergir no processo de apropriação e dominação do espaço, objeto de intervenção. Para o capital e o Estado, quase sempre 
a condição de recurso materializa-se na expansão econômica, na medida em que alguma matéria da natureza é incorporada no processo produtivo. Quando tal recurso se esgota, acelerado pelo tempo do capital, perdendo sua potencialidade produtiva, as empresas migram para outras áreas que possam oferecer novas oportunidades à acumulação, ou seja, nessa perspectiva, tem-se o território como recurso, estoque de matérias aptas ao metabolismo econômico. Se pensarmos na cartografia das madeireiras e da agropecuária, por exemplo, veremos como o capital se desloca para as novas áreas, expandindo as fronteiras na Amazônia, como ocorre no norte de Rondônia, leste do Acre e sul do Amazonas, cujos processos evidenciam a pilhagem ambiental e territorial em Áreas Protegidas (COSTA SILVA et.al., 2018; COSTA SILVA et. al., 2019).

Pode-se falar em alienação do território ao entendermos que no espaço, objeto de ação do capital, há toda uma vida coletiva, socialidades urbanas e rurais que exprimem graus diversos de representação, apropriação simbólica e convívio com a natureza. Milton Santos contribui com o debate, ao propor o território como totalidade social, como território usado:

O território não é apenas o resultado da superposição de um conjunto de sistemas naturais e um conjunto de sistemas de coisas criadas pelo homem. O território é o chão e mais a população, isto é, uma identidade, o fato e o sentimento de pertencer àquilo que nos pertence. O território é a base do trabalho, da residência, das trocas materiais e espirituais e da vida, sobre os quais ele influi (SANTOS, 2000, p. 96).

Vê-se, nessa compreensão, que o território usado reúne as dimensões da vida social (política, econômica e natural), aparecendo, sobretudo, como destino humano, como devir do processo social. Trata-se da totalidade-mundo no universo social dos lugares, no qual se configuram as teias da vida que produzem a socialidade local, a solidariedade orgânica que, com conflitos, contradições e complementariedades, definem a regularidade dos lugares (SANTOS, 1996; PORTO-GONÇALVES, 2017). Nesse sentido, o território usado é o conjunto da vida social, sendo, pois, o quadro permanente, mas não imutável, que rege a coletividade humana, no qual o destino deve ser pensado como recusa à alienação (RIBEIRO, 2005; HAESBAERT, 2004).

No mundo amazônico os lugares vividos por comunidades rurais, populações de pequenas cidades, experienciadas por povos e comunidades tradicionais, são, pois, territórios de vida construídos cotidianamente (MAB, 2004; ALMEIDA, 2009; 
IORIS, 2010). Contudo, quando há inserção territorial do capital, em geral tem-se um território da morte, esvaziado de vidas que animavam e davam outro sentido histórico aos lugares transformados pelos sistemas de engenharia que modificaram a composição orgânica do meio geográfico, na medida em que o valor de trocar, decorrente da ação do capital, projetou relações exteriorizadas no território, afirmando a multidimensionalidade e multiescalaridade do meio geográfico como espaço híbrido (SANTOS, 1996).

Para as comunidades rurais ou para a maioria dos habitantes das cidades, o território é abrigo, morada, local de trabalho, espaço material e imaterial indissociável de suas condições mais básicas à existência humana (GOTTMANN, 1975; SANTOS, 2000). Para muitos, homens e mulheres, no território alimenta-se a cultura, o simbólico, o trabalho, as relações pessoais, a coexistência, o tempo passado no presente, tornando-se espaço que reúne todas as condições do devir social (PORTOGONÇALVES, 2017). Assim, o território - como morada e abrigo - constitui o conjunto de ação e possibilidades que delineiam a vida social em suas diversas escalas geográficas. Não se pode, nestes termos, ignorar a perspectiva ativa que o território tem para com seus habitantes, construindo um ator indissociável de seus destinos, um ator coletivo que pertence a todos, um cotidiano compartido (SANTOS, 2000; RIBEIRO, 2005; KRENAK, 2019).

Contudo, a alienação do território decorre de projetos hegemônicos que roubam às coletividades o seu destino, na medida em que este destino passa a ser o destino do capital territorializado. Com aceleração dos fluxos, das imagens, das representações construídas pelas ideias hegemônicas, tem-se um destino disputado, por vezes subjugados às normas e às políticas exógenas que tendem a fragmentar o território como estranhamento à coletividade. As hidrelétricas fazem exatamente isso quando privatizam a natureza, quando transformam os rios, os cursos d'águas, em represas, espaço estranho e estranhamente vivido. A natureza, o rio, o lugar, a floresta, que antes eram acessíveis, passam a privar os sujeitos, que outrora faziam do território usado sua contemplação de vida. Um dos recursos discursivos utilizados no processo de alienação dos territórios, ou seja, das coletividades que formam o território, derivam do conhecimento técnico-científico, esboçados nos estudos de impactos ambientais e seus respectivos relatórios, quando dolosamente excluem, 
RICARDO G. C. SILVA, GISELE D. O. B. CUNHA \& REBECA C. FERREIRA

minimizam, ignoram comunidades tradicionais do escopo dos atingidos diretamente pelas grandes obras, como analisaremos em outra seção.

\section{Hidrelétricas e o uso coorporativo do território}

O discurso comum à justificativa de hidrelétricas na região amazônica é a da indissociabilidade da produção energética com o desenvolvimento econômico-social. Em muitas propagandas era ordinário ler nos outdoors, ou assistir nas peças publicitárias divulgas na mídia regional, a narrativa de que "energia é desenvolvimento!" (SEVÁ FILHO, 2008; CAVALCANTE et. al, 2011; WERNER, 2012; LIMA \& COSTA SILVA, 2018). Nos lugares onde se territorializa, esse discurso anuncia à população maiores e melhores condições para aprimorarem o bem-estar social, fruto da geometria dos empregos a serem criados na região. De fato, no período de construção há criação de milhares de empregos formais, para, em seguida, com o término das obras, reduzir-se ao mínimo necessário à produção energética, ficando os municípios com os passivos sociais decorrentes dessas grandes obras, dentre eles, o aumento populacional decorrente da migração induzida (FEARNSIDE, 2015; SCABIN et. al. 2015; LIMA; COSTA SILVA, 2019).

A questão central é que a ideia de energia e desenvolvimento aos poucos se desloca de sua suposta centralidade social-local, para dar vazão ao lema "energia como commodity", o que indica o uso corporativo do território (SANTOS \& SILVEIRA, 2001; VAINER, 2007; CASTRO 2012), quando a expansão energética produz espoliação da natureza, da população local e dos lugares, erigindo, assim, a alienação do território. A instalação desses modernos sistemas de engenharia hidroelétricos na Amazônia sempre abriu debates e questionamentos acerca dos impactos territoriais nas localidades, no que diz respeito aos impactos ambientais e seus desdobramentos socioeconômicos.

O planejamento referente a esses projetos restringiu-se à hegemonia dos planos setoriais do governo, não abarcando análises mais profundas que relacionassem os projetos com as condições territoriais ou vontade da sociedade local que ocupa a região, principalmente dos lugares diretamente atingidos (CASTILHO, 2019). As agências governamentais de planejamento (Sudene, Sudam, Sudeco) limitaram-se em sua função de planejar as regiões, de modo que o efetivo planejamento regional foi sendo operacionalizado por agências estatais setoriais, 
vinculadas aos grandes setores de infraestrutura do país. Estas, sim, delinearam e tomaram decisões sobre o planejamento regional (Eletrobrás, Vale do Rio Doce, Furnas, Petrobrás), resultando na reconfiguração territorial do Brasil (WERNER, 2012; FGV, 2017; VAINER, 2007; CASTILHO, 2019).

A implantação dos grandes projetos de infraestrutura foi decisiva para produzir uma forma específica de integração do país, gerando vínculos entre os grandes centros urbanos do Sudeste ao restante da nação. O esgotamento dos recursos hídricos próximos aos grandes centros de consumo deflagrou o avanço da fronteira energética para a região Norte do país (WENER, 2012; VAINER, 2007; (CASTILHO, 2019). Nesse processo, muitas comunidades locais da Amazônia tiveram que ser removidas e desterritorializadas para a instalação de hidrelétrica, ocorrendo a transformação da região em verdadeira fronteira energética. O exemplo desta política energética privatizada foi a instalação do Complexo do Madeira no estado de Rondônia. Juntas, as duas usinas produzem em torno de 6.500 MW para o Sistema Interligado Nacional - SIN. A construção de hidrelétricas ocasionou, na região, um processo de migração e urbanização das atividades econômicas, deslocamentos compulsórios e degradação ambiental severa, como ocorreu em Altamira, no Pará, e Porto Velho, em Rondônia (WENER, 2012; CAVALCANTE et. al, 2011; LIMA \& COSTA SILVA, 2018).

No espaço amazônico, marcado pela histórica ação seletiva do Estado no planejamento regional, a chegada de grandes obras à região tem, tradicionalmente, produzido um expressivo passivo social e ambiental, decorrente de inúmeras e graves violações aos direitos humanos dos grupos locais pela expropriação de territórios para instalações de grandes projetos (CASTRO, 2012; PORTO-GONCALVES, 2017; COSTA SILVA \& LIMA; CONCEIÇÃO, 2018). Tal expropriação é marcada nas abrangentes desterritorializações, evidenciadas no deslocamento de pessoas e famílias de suas habitações, por restrições de acesso aos recursos naturais, pela perda das fontes de renda, pela destruição das relações de parentescos e vizinhança, por conflitos, violência e coerção entre outros desdobramentos (CDDPH, 2010; MAB, 2004).

Tal quadro de acontecimentos resultou em relações de poder extremamente assimétricas, com prejuízos a muitas comunidades tradicionais, povoadas e, mesmo, nas cidades que materializam esses processos. Para os "empreendedores", palavra 
eufêmica para designar o capital hidrelétrico, tais grupos sociais representam obstáculos ao desenvolvimento econômico do país, porque podem desencadear ocupações, manifestações, paralisação de obras, processos judiciais, riscos operacionais, prejuízos financeiros (custo social), e eventuais danos à imagem das empresas, entre outros (SCABIN et al., 2015).

Nos últimos anos, tais projetos voltaram à pauta, principalmente na modalidade de megaempreendimentos hídricos (são exemplos: a transposição das águas da bacia do Rio São Francisco, UHE de Belo Monte e o Complexo do Madeira). Ocorre que, na atualidade, tais projetos não estão mais sob total controle de Estado brasileiro. Com as privatizações desencadeadas no final dos anos 1990, o setor de infraestrutura passou a ser controlado por entes privados. Logo, os processos de planejamento e controle territorial passaram das grandes estatais para o controle das empresas privadas (VAINER, 2007; CASTRO, 2012; WERNER, 2012), tornando-as, praticamente, soberanas em tal quesito, daí evidenciado o uso corporativo do território para o capital, consequente à alienação do território para as comunidades tradicionais amazônicas (SANTOS, 1996 e 2000; CASTRO, 2012; CASTILHO, 2019).

Os chamados Grandes Projetos de Investimentos (GPI) continuaram a transformar os espaços regionais, só que, diversamente de como ocorria anteriormente, com as decisões sobre planejamento sendo ditadas pelos grandes consórcios. Tais empresas privadas tornaram-se responsáveis por decompor e fragmentar regiões inteiras, conforme seus interesses. Estes interesses são quase sempre globais, o que faz deles eventos globais e locais, ao mesmo tempo (SANTOS, 2000; VAINER, 2007; CASTRO, 2012). Deve-se lembrar que a natureza dos processos decisórios dos grupos econômicos controladores se origina em um ambiente avesso à participação pública, à margem de qualquer debate. Antes de realizar a apropriação do território, propriamente dito, o rascunho do plano é desenhado nos espaços de governanças do capital, ou seja, nos corredores e gabinetes, com realização de apoios e coalizões políticas nem sempre movidas por motivos republicanos. Nos espaços de governança convergem os ajustes dos projetos industriais, controle territorial, empreendimentos econômicos e projetos políticos, todos unidos no mesmo objetivo de auferir lucros e benefícios, e para tanto, se empenham na busca de financiamentos públicos e privados, visando a concretização do projeto almejado (SANTOS \& SILVEIRA, 2001; CUNHA \& COSTA SILVA, 2019). 
Não raro, verifica-se que agentes políticos e empresas nacionais $e$ internacionais estabelecem associações e mobilizam elites locais para exercer a apropriação de territórios, como ocorreu em Porto Velho, capital do estado de Rondônia, quando das campanhas do Consórcio Santo Antônio Energia para "convencer" a sociedade local a apoiar o aumento da cota do lago da barragem. Tal conjectura produziu, e ainda produz, uma nova geografia física, econômica e política que retalha o território nacional em fragmentos, numa mistura de global com local, criando distritos ou enclaves controlados pelos entes privados, resultando no uso corporativo do território (CAVALCANTE et al., 2011).

Diante deste novo quadro, o Estado neoliberal repassa aos espaços de governanças do capital as diretrizes de planejamento territorial, abstendo-se, inclusive, de sua responsabilidade de mediar e liderar práticas de cooperação federativa. Tal ausência estatal desencadeia conflitos entre os próprios entes federados, do qual saem vencedoras as empresas privadas, que se beneficiam dos verdadeiros "leilões" dos locais oferecidos pelos entes federados, tratando-se de uma verdadeira guerra dos lugares (SANTOS, 2000), onde são disputados os atributos da natureza em sua potencialidade mercantil, ou seja, o uso corporativo do espaço implica a prática do território como recurso (GOTTMANN, 1975). O ente que oferecer os locais mais atrativos para a instalação dos megaprojetos (vantagens fiscais, fundiárias, ambientais) "leva o prêmio" da sua instalação. É o mercado livre e concorrencial das localizações que contribui para multiplicar as rupturas socioterritoriais, acirrando ainda mais a fragmentação do território e os conflitos sociais (SANTOS \& SILVEIRA, 2001; VAINER, 2007; PORTO-GONÇALVES, 2017).

Destaca-se a importante atuação dos consultores internacionais e das agências multilaterais neste processo de fragmentação, ao difundirem amplamente a ideia de planejamento territorial competitivo e das estratégias territoriais empreendedoristas, estimulando os entes federados a tratarem seus territórios como se fossem mercadorias colocadas à disposição dos investimentos internacionais (SANTOS, 2000; VAINER, 2007; IORIS, 2010; FEARNSIDE, 2015).

Também é importante registrar que este "neo-localismo", evidenciado no discurso do desenvolvimento social-local, reveste-se em práticas de coronelismo do passado, só que, agora, com uma nova roupagem. Ele nada mais é que a permanência do velho regionalismo do cenário político brasileiro, só que nas suas 
projeções sobre os territórios. A prática deste regionalismo se revela, atualmente, na articulação política desempenhada pelas elites e oligarquias locais, até então decadentes, aliadas aos grupos hegemônicos de escala nacional (SANTOS; SILVEIRA, 2001; VAINER, 2007), que na escala dos lugares, são acionadas para garantir a adesão política à narrativa de hidrelétrica e desenvolvimento e, pari passu, impulsionar a expansão da fronteira em áreas naturais ou áreas protegidas (LIMA \& COSTA SILVA, 2018; LIMA, 2020).

Ora, se o processo de urbanização e industrialização contribuiu para reduzir em alguma medida o controle e o poder dos coronéis nas regiões, as oligarquias tradicionais ainda detêm um expressivo controle da máquina eleitoral local, constituído em força político-parlamentar que não pode ser desprezada. E tal força política, não raras vezes, é provocada a participar da implantação de grandes empreendimentos, oferecendo o prestígio e apoio político, em troca de benefícios decorrentes destes projetos. Este padrão de constituição de interesses sobre os locais tem importante consequência na escala nacional, tendo em vista que reproduz e reforça as formas pretéritas de articulação entre o local, o estadual e o nacional (LIMA, 2020). Tais padrões se reatualizaram e voltaram à cena, não sendo incomum encontrar-se uma empresa multinacional negociando alianças com grupos tradicionais locais para construir base de sustentação (e pressão) em favor de um determinado empreendimento.

Neste contexto, surgem coalizões híbridas que combinam às práticas dos velhos caciques com o Know-how repaginado e atualizado de estratégias empresariais altamente agressivas e competitivas. Uma vez formada a coalizão, ela obtém, sem dificuldades, apoio em todos os níveis do poder, seja no legislativo, seja no executivo, a favor da construção das grandes obras nas regiões cobiçadas. Logo, as coalizões de poder conseguem avançar na organização territorial, apropriando-se dos locais, porque sabem estabelecer articulações com todos os grupos necessários, sejam eles locais, regionais, nacionais ou internacionais, sacramentando uma união de interesses dominantes, ao passo que, igualmente, aproveitam as fragilidades das condições sociais (escola, saúde, emprego) para vender as contrapartidas, quando, em geral, essas grandes obras só fazem ampliar a demanda social em investimentos públicos. 
Cumpre destacar que o próprio Estado desempenha papel central na concretização destes projetos ao imprimir facilidades na sua implementação, seja com ajuda financeira, por meio de empréstimos em instituições públicas, seja na concessão de subsídios fiscais ou ambientais. Isto é, ele transforma-se em um agente importante nesta dinâmica territorial predatória e excludente.

As hidrelétricas, como grandes sistemas de engenharia, modificam a composição orgânica do território, produzem relações sociais e políticas em múltiplas escalas, operando no sentido de remover os possíveis obstáculos políticos à sua instalação. A propaganda, as alianças políticas e institucionais locais, a violência simbólica, todos esses processos convergem à assunção do capital no lugar. $O$ conhecimento supostamente científico-técnico também é um instrumento dessas práticas espaciais, na medida em que o real é ajustado, na qualidade e na escala do fenômeno, para parecer ínfimo quando do debate social referente à população diretamente atingida, sobretudo, as comunidades ribeirinhas (CUNHA \& COSTA SILVA, 2019; CAVALCANTE et. al., 2011). Por vezes, o universo das comunidades tradicionais que vivem do rio e que têm o território como morada, como abrigo, como universo de realização social, é totalmente ignorado nas estatísticas e nos relatórios científicos que alicerçam a construção dessas grandes obras. Analisaremos tal situação evidenciada nos estudos de impacto ambiental da Hidrelétrica de Tabajara, a ser construída no rio Machado, estado de Rondônia.

\section{Hidrelétrica de Tabajara e a alienação do território}

Atualmente, o projeto de construção da hidrelétrica de Tabajara, a ser construída no rio Machado, conforme o Instituto Brasileiro do Meio Ambiente e dos Recursos Naturais Renováveis - IBAMA (BRASIL, 2020) está em fase de ajustes do Estudo de Impacto Ambiental (EIA) e seu respectivo Relatório de Impacto Ambiental (RIMA). A problematização a ser feita, nesta seção, analisa esse documento técnicocientífico, correlacionando-o com as projeções e "virtualidades" criadas no lugar para justificar a construção desta hidrelétrica. Iniciaremos pelas configurações territoriais do município de Machadinho D’Oeste, em seguida, discute-se as potencialidades prometidas pelo capital energético, finalizando com o debate da alienação do território para com as comunidades tradicionais diretamente atingidas. 
RICARDO G. C. SILVA, GISELE D. O. B. CUNHA \& REBECA C. FERREIRA

No norte de Rondônia estão localizadas três hidrelétricas (Mapa 1), as quais duas foram recentemente construídas. A primeira, a UHE de Samuel, rio Jamary, localizada no município de Candeias do Jamary, está a $45 \mathrm{~km}$ da cidade de Porto Velho, construída entre 1982 e 1989, compôs o conjunto de grandes obras de infraestrutura que alicerçaram o desenvolvimento econômico e social do então recente Estado de Rondônia (BRASIL, 1996). Sua capacidade geradora instalada é de 216 MW, atendendo parte dos municípios de Rondônia e Acre. Para Fearnside (2004), a UHE de Samuel foi um dos maiores erros de engenharia e impacto ambiental na Amazônia, com deslocamento compulsório de centenas de famílias, muitas delas jamais indenizadas, que migraram para a periferia de Porto Velho.

Mapa 01: Principais Hidrelétrica em Rondônia (2019)

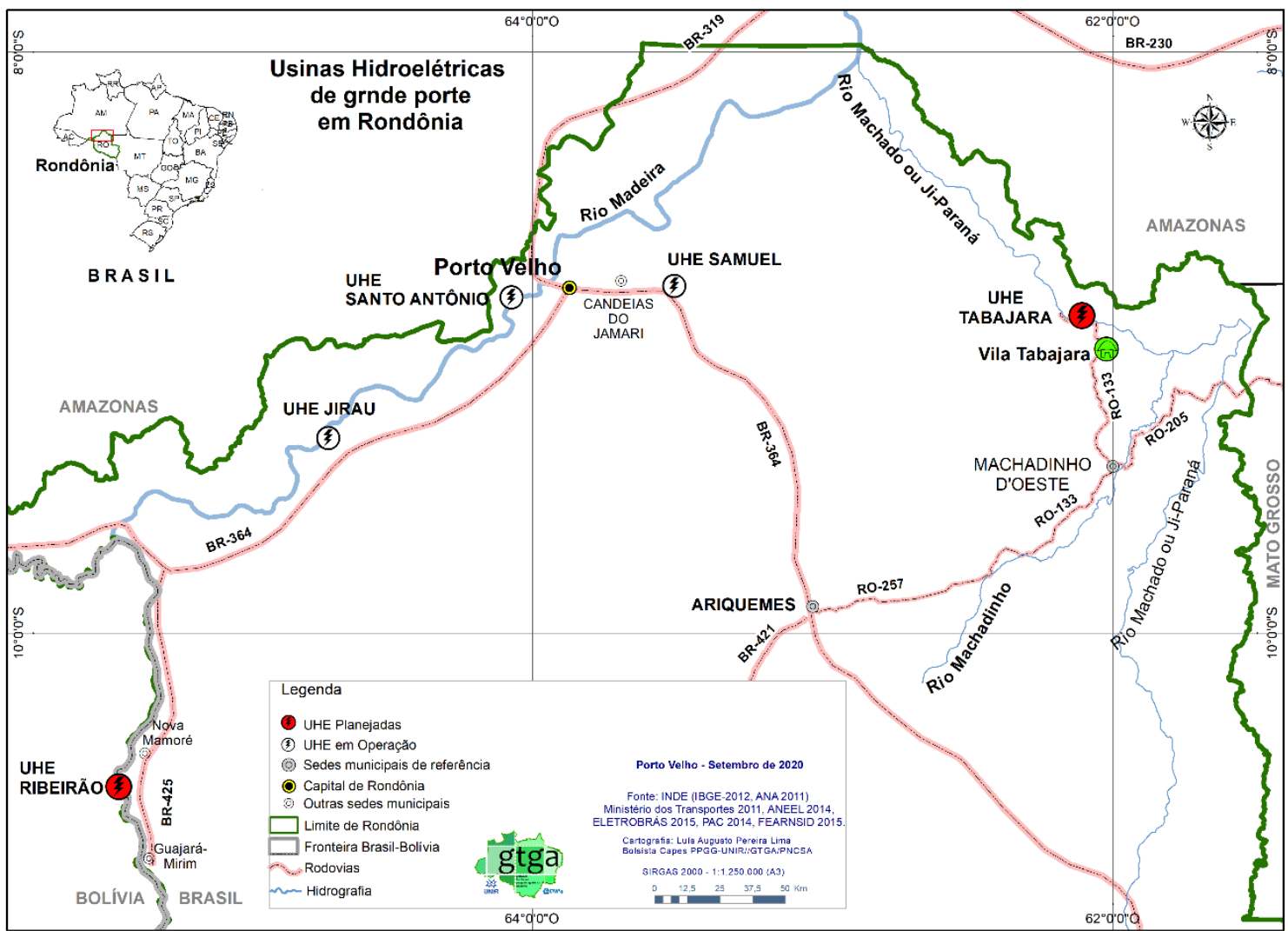

Fonte: GTGA/UNIR

No período recente (2008-2016), as UHE's Jirau (3.750 MW) e Santo Antônio (3.568 MW) foram construídas no rio Madeira, formando o Complexo Hidrelétrico do Rio Madeira, cuja potência total soma 7.318 MW. Os impactos ambientais e sociais foram analisados e denunciados na Justiça estadual. Contudo, a desterritorialização de comunidades ribeirinhas à montante de Porto Velho, sobretudo nos históricos 
distritos de Mutum-Paraná (foi totalmente despovoado), Jaci-Paraná e Abunã, todos eles nascidos em função da lendária Estrada de Ferro Madeira Mamoré, sofreram impactos socioambientais que resultaram em uma cartografia da desterritorialização dos povos amazônicos (ALMEIDA, 2009; CAVALCANTE et al., 2011; LIMA \& COSTA SILVA, 2018) e que novamente pode ocorrer na região do Projeto Hidrelétrico de Tabajara, município de Machadinho do Oeste (FERREIRA, 2017; CUNHA \& COSTA SILVA, 2019).

O município de Machadinho D'Oeste localiza-se no norte de Rondônia, na divisa com o Estado do Amazonas, com acesso rodoviário através das BR-364 e RO253/RO-133, cuja distância de Porto Velho é de 295 km (Mapa 01). No Censo Demográfico de 2010, a população registrada foi de 31.135 pessoas e, em 2019, esse dado demográfico foi estimado em 39.991 habitantes (12ำ no ranking estadual), o que representa um crescimento de $28 \%$, no período. Se compararmos com Rondônia (1.805.788 pessoas), que obteve $12 \%$ de crescimento, verifica-se que Machadinho D'Oeste (Figura 1) vivencia um acentuado aumento populacional, mais que o dobro da média estadual (IBGE, 2020). Ainda, se compararmos com Porto Velho, no período citado, a capital de Rondônia teve um aumento de 21,23\%, cujo desempenho se deve, em boa parte, à construção de duas hidrelétricas no rio Madeira (UHE's Jirau e Santo Antônio), fator indutor de migração para o mercado de trabalho, o que repercute no crescimento total de habitantes.

Em termos de indicadores socioeconômicos, conforme dados disponíveis no Portal Cidades e Estados do IBGE, o PIB per capita de Machadinho D'Oeste, em 2017, correspondeu a $\mathrm{R} \$ 15.724,60$ (44ํㅡ no ranking); o Índice de Desenvolvimento Humano Municipal (IDHM), em 2010, foi de 0,596, considerado baixo (45ำ na classificação estadual), enquanto o mesmo indicador para Rondônia atingiu 0,690 (considerado médio); quanto aos rendimentos, em 2017, o salário médio mensal era de 1,8 salários mínimos (28ํㅜ classificação estadual), e a proporção de pessoas ocupadas em relação à população total atingiu $9 \%$, ocupando a $36^{\circ}$ classificação estadual. Outro indicador importante refere-se aos domicílios com rendimentos mensais com até meio salário mínimo por pessoa, que atingira $44 \%$ da população nessas condições, posicionando o município em 12º dos 52 municípios do estado (IBGE, 2020). O crescimento demográfico está associado à expansão da fronteira 
RICARDO G. C. SILVA, GISELE D. O. B. CUNHA \& REBECA C. FERREIRA

agrícola e, principalmente, às expectativas socioeconômicas com a construção da hidrelétrica de Tabajara, acelerada desde 2010, quando se noticiou a construção.

Figura 1: Vista parcial da cidade de Machadinho D'Oeste (2019)

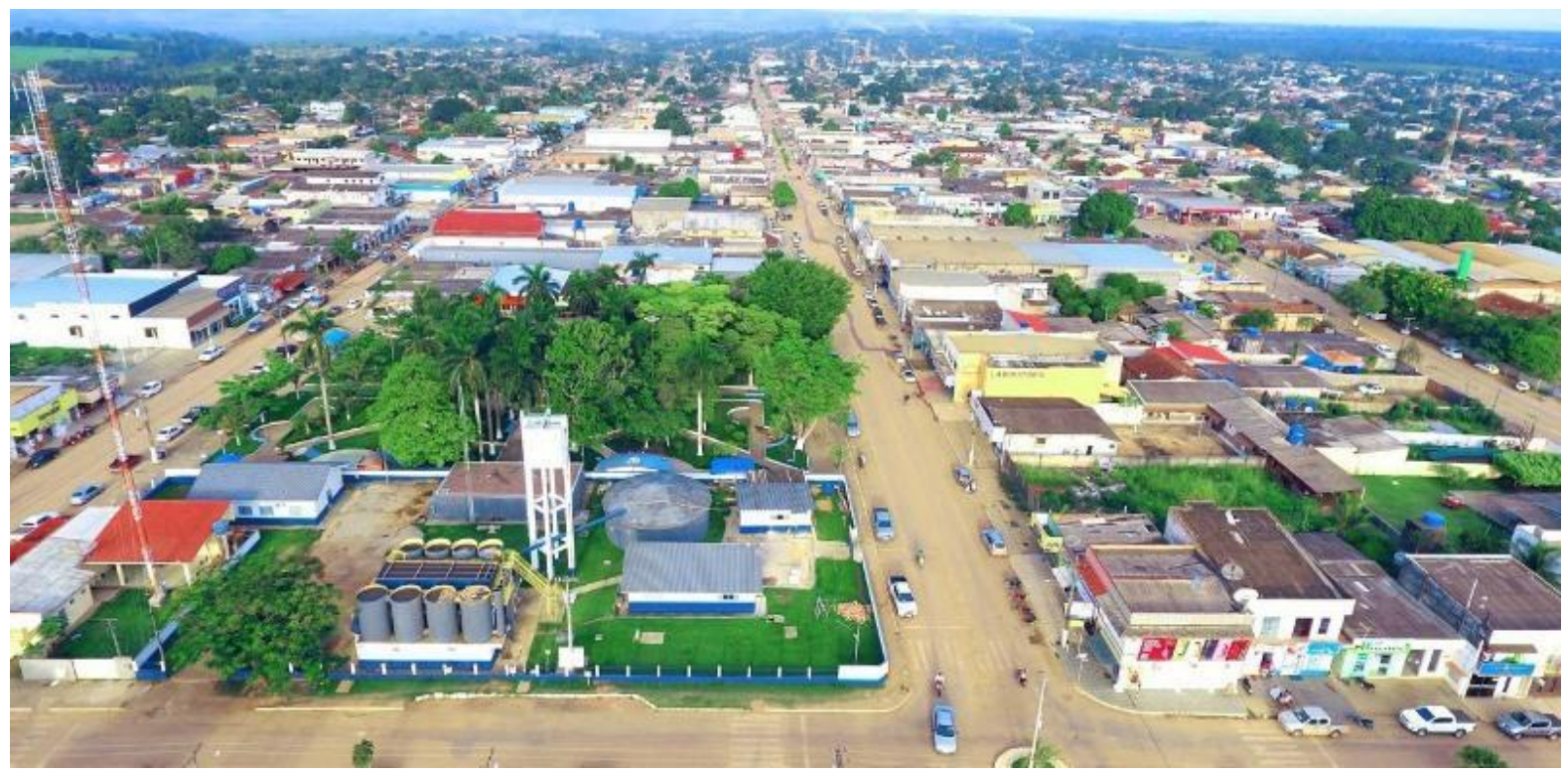

Fonte: Diário da Amazônia (29/10/2019).

Nos últimos anos, as variáveis que impulsionam a fronteira agrícola na região de Machadinho (Figura 1) mostram-se no crescimento da agropecuária e, especialmente, na territorialização da soja. Essas variáveis desdobram-se em vários processos interdependentes, como o aumento do preço da terra rural, acréscimo do rebanho bovino e, principalmente, extração legal e ilegal de madeira, o que resulta no aumento do desmatamento. Na produção agrícola, o município é um polo menor de produção cafeeira, com participação expressiva da agricultura camponesa. Contudo, não se deve creditar à economia campesina fator preponderante na expansão da fronteira, dado que isso é condição de acumulação de capital.

No conjunto, esses processos espaciais mobilizam a fronteira, cujo movimento espacial alcançou as Áreas Protegidas (Unidades de Conservação e Terras Indígenas), localizadas nos limites entres os estados de Rondônia e Amazonas. Evidentemente, em período anterior, a extração madeireira ilegal sempre movimentou a economia regional, sendo objeto de inúmeras ações de fiscalização ambiental (estadual e federal), com vistas a combater o crime organizado que atuava na região. O setor madeireiro é o carro-chefe da pilhagem ambiental na Amazônia (PÚBLICA, 
2019), repercutindo na expansão da fronteira que, atualmente, ultrapassou os limites jurídico, político e territorial que separa o espaço da agropecuária e o espaço das Áreas Protegidas ou Territórios Protegidos. Com o deslocamento espacial da soja, o efeito no mercado de terras é eminente, gerando uma verdadeira corrida pela terra que não respeita os ordenamentos territoriais. Esse é o quadro geral da fronteira em Machadinho D'Oeste.

O segundo processo decorre da psicoesfera do capital hidrelétrico. $\mathrm{Na}$ análise das transformações espaciais produzidas por modernos sistemas de engenharia, a exemplo de hidrelétricas, Milton Santos elaborou dois conceitos para compreender essas metamorfoses inerentes à modernização dos lugares em sua composição técnica, ou seja, mudanças na composição orgânica do espaço. Trata-se de tecnosfera e psicoesfera ${ }^{2}$, conceitos pares e indissociáveis. O primeiro refere-se ao conjunto dos objetos técnicos - a hidrelétrica em si e seus circuitos de transmissão de energia - resultado da artificialização do espaço. Já a psicoesfera corresponde ao "reino das idéias, crenças, paixões e lugar da produção de um sentido [...] fornecendo regras à racionalidade ou estimulando o imaginário" (SANTOS, 1996, p. 204). A psicoesfera envolve o cotidiano local nos fluxos de ideias e crenças de que algo moderno chega à sociedade, sendo, pois, sentidos, anseios e valores submetidos à lógica do capital que se pretende ser hegemônico nos lugares onde se instalam, sobretudo no período de construção, momento em que ocorrem intensas mudanças socioeconômicas nos lugares, a exemplo da construção de hidrelétricas na Amazônia. A psicoesfera antecede à tecnosfera, como ocorreu em Porto Velho, referente à construção do Complexo Hidrelétrico do Rio Madeira, em Altamira e região, quando da construção de UHE de Belo Monte, ou nas pequenas hidrelétricas que ainda não foram construídas, mas que seus anúncios já potencializam transformações territoriais, processo que Lima (2020) qualificou de antecipação temporal, ao estudar a proposta de hidrelétrica no rio Aripuanã.

A psicoesfera do capital hidrelétrico tem efeito de arrastro na região de Machadinho D'Oeste. No espaço rural diretamente atingido, na área de construção da hidrelétrica, há todo um processo de ocupação desordenada, invasões de Áreas

\footnotetext{
2 "Tecnosfera e Psicosfera são redutíveis uma à outra. [...] Tecnosfera e psicosfera são os dois pilares com os quais o meio científico-técnico introduza racionalidade, a irracionalidade e a contraracionalidade, no próprio conteúdo do território (SANTOS, 1996, p. 204).
} 
Protegidas, violência, pressão econômica na comercialização de terras, configurandose em verdadeira coerção territorial. $\mathrm{Na}$ cidade, sede das empresas locais vinculadas aos circuitos econômicos direto e indireto da construção hidrelétrica, todo o espaço urbano é atingindo pelo processo espacial produzido pelas grandes obras, com efeitos devastadores que ampliam a desigualdade social, dado a inflação nos custos de vida urbana (aluguel, terreno urbano, alimentação, serviços diversos) ${ }^{3}$.

Tais situações aceleram-se, dado o universo financeiro que mobiliza os atores locais e nacionais a defender a construção da hidrelétrica, sendo um processo político poderoso, sobretudo, quando a psicoesfera do capital hidroelétrico povoa o imaginário social, vendendo-lhes a ilusão de que a energia é o caminho sustentável para se garantir o desenvolvimento social. As cifras e a potência que este sistema de engenharia assume no espaço local mobiliza os agentes econômicos em seus interesses imediatos, no que concerne a reprodução do capital da elite política e econômica da região. O projeto de construção da Hidrelétrica de Tabajara apresenta um custo médio estimado de $\mathrm{R} \$ 5$ bilhões, com potência prevista de 400 megawatts e capacidade a atender 1,45 milhão de pessoas (ESTADÃO, 2019), ou seja, equivale à população das cidades de Belém ou Porto Alegre, ou $80 \%$ da população do estado de Rondônia. Para se ter a dimensão política dessa proposta na escala local, podemos comparar com o PIB de Machadinho D'Oeste, que em 2017 registrou R\$ 607.111,21 (IBGE, 2020). O orçamento da hidrelétrica supera em oito vezes o PIB municipal. Pode-se imaginar o furor político causado na cidade, conduzido pelos agentes hegemônicos (governo e consórcios de empresas interessadas na construção), principalmente quando se estima que a construção pode gerar 10 mil empregos diretos e 20 indiretos 4 .

A escala geográfica dos agentes hegemônicos converte a cidade e o campo em espaços da solidariedade organizacional do capital, da ordem vertical que muda o cotidiano, tornando, de certa forma, os lugares obedientes à lógica exógena que se internalizou, que se territorializou na escala local. A psicoesfera caminha para o uso

\footnotetext{
${ }^{3}$ Ver: https://www.diariodaamazonia.com.br/anuncio-de-hidreletrica-ja-aumenta-procura-de-casasem-machadinho/

4 "... a usina será construída na cachoeira 2 de Novembro, no rio Machado, no distrito de Tabajara, de Machadinho D'Oeste e deve gerar pelo menos 10 mil empregos diretos e 20 mil empregos indiretos". https://www.diariodaamazonia.com.br/hidreletrica-de-tabajara-sera-deliberada-por-jair-bolsonaro/
} 
corporativo do território da grande empresa, de modo a sobressair os interesses corporativos sob os interesses púbicos (SANTOS, 1996). Assim, a política da empresa constitui um espaço de governança, donde a propaganda do progresso, dos empregos e das rendas, e, inclusive, do desenvolvimento "sustentável", relega à construção do destino de uma comunidade, de uma cidade, do universo de cidadãos, aos desejos privatistas do capital hegemônico, pois, "o modelo hegemônico é planejado para ser, em sua ação individual, indiferente a seu entorno" (SANTOS, 2000, p.107), de modo que se cristaliza a dialética do uso corporativo do território para o capital, e respectiva alienação do território para a população mais atingida.

A alienação do território, partindo do Estudo de Impacto Ambiental (EIA) e Relatório de Impacto Ambiental (RIMA) da Hidrelétrica Tabajara, mostra-se, principalmente, na invisibilidade das comunidades ribeirinhas no jogo metodológico destes relatórios técnico-científicos (FERREIRA, 2017; CUNHA \& COSTA SILVA, 2019). Esse processo ficou mais evidente nas questões elencadas no Laudo Pericial do Ministério Público Federal, de autoria da Perita em Antropologia Rebeca Campos Ferreira, que indicou inúmeras limitações técnicas nestes estudos ( FERREIRA, 2017), principalmente no subdimensionamento da área de influência da UHE Tabajara, de modo que a área impactada deverá ser bem maior do que a identificada nos estudos. Esta mesma falha foi verificada nas hidrelétricas de Belo Monte, Santo Antônio e Jirau. Longe de ser um erro eventual ou uma inconsistência culposa, as empresas de consultoria costumam diminuir intencionalmente as áreas de influência dos projetos para diminuir os custos sociais da obra, tornando-a viável economicamente, mesmo que enormes e impagáveis passivos socioambientais sejam produzidos.

Ao analisar os volumes II e III do processo de licenciamento, junto ao Ibama, foram encontradas diversas informações técnicas produzidas por servidores do órgão sugerindo alterações no parâmetro utilizado no Termo de Referência (TR) apontando a necessidade de ampliação do desenho amostral da área de influência. Contudo, o processo continuou sem a ampliação sugerida pelo corpo técnico do Ministério Público Federal em Rondônia (FERREIRA, 2017). Ademais, o TR utilizou o parâmetro de divisão de áreas impactadas como orientador dos estudos ambientais consistente em: a) ADA: Área Diretamente Afetada; b) AID: Área de Influência Direta; e c) All: 
RICARDO G. C. SILVA, GISELE D. O. B. CUNHA \& REBECA C. FERREIRA

Área de Influência Indireta. Tal parâmetro é rotineiramente utilizado nos TR's de empreendimentos hidrelétricos.

Ocorre que tal divisão serve melhor ao estudo do meio biofísico, que ao meio sociocultural, sendo demasiadamente limitada à análise dos impactos sociais do projeto. O principal efeito da adoção desta classificação consiste na ênfase dos impactos sobre o território (para a empresa, entendido como espaço meramente físico, desprovido de qualquer outra característica) e não do território tradicional/cultural, espaço coletivo das comunidades rurais, onde está diluindo os processos socioculturais desses grupos sociais ( FERREIRA, 2017), daí ser o território da vida, do universo social das territorialidades vividas (KRENAK, 2019).

Mapa 2: Configuração territorial da UHE Tabajara (2019)

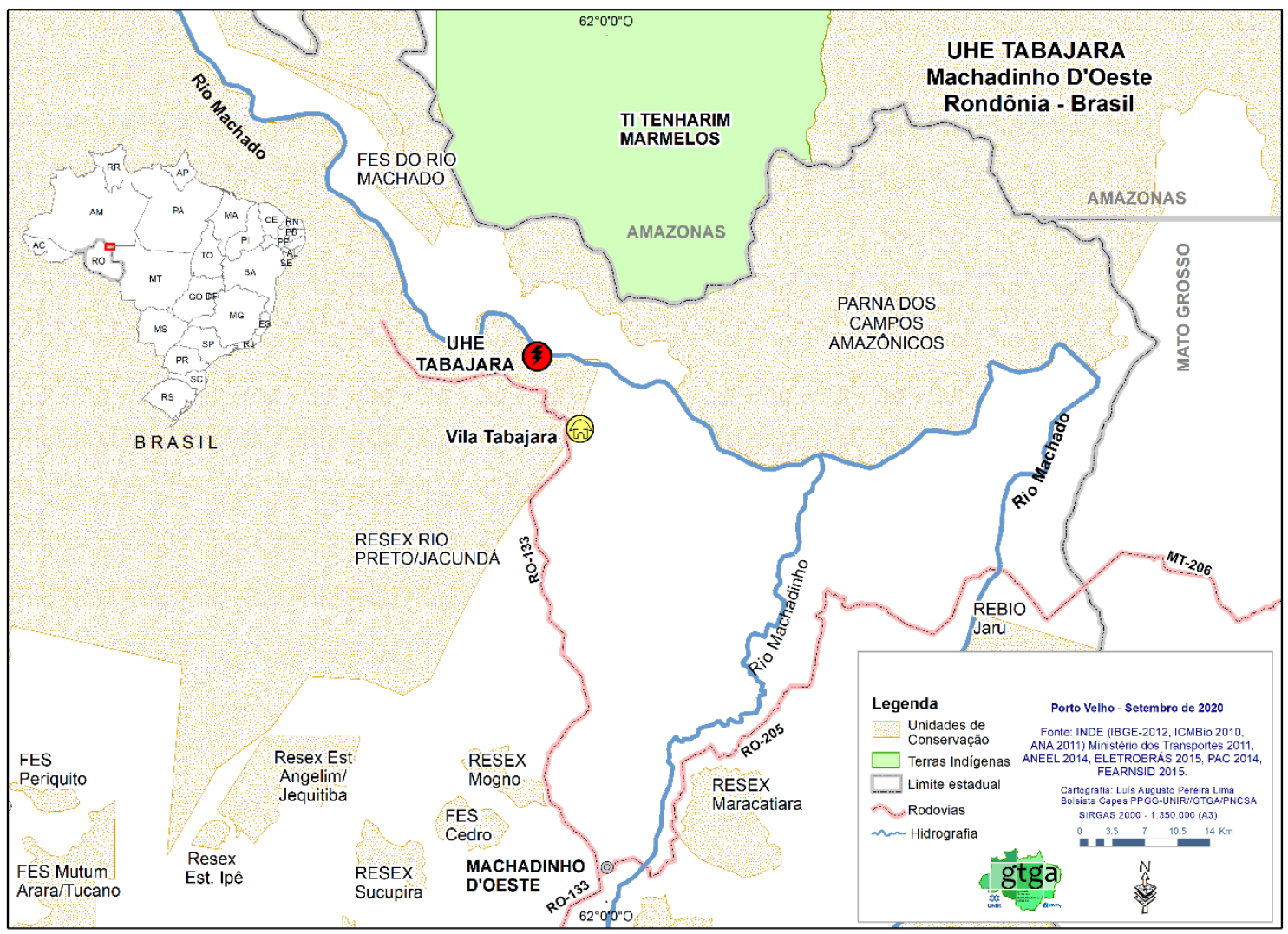

Fonte: GTGA/UNIR.

A suposta área de influência descrita no EIA da UHE Tabajara restringiu-se às áreas das obras de engenharia (barragens, canteiros de obras, estradas de acesso, etc), e não incluíram áreas próximas (onde se localizam vários territórios tradicionais) que muito provavelmente também serão impactadas (Mapa 2). Em nenhum momento 
dos estudos foram mencionados os critérios que levaram a delimitação da área de influência. Também não foram tecidas informações sobre a existência de comunidades tradicionais localizadas nestas áreas, ou em áreas próximas. A única comunidade mencionada no EIA foi o Distrito de Tabajara, visto que, exatamente sobre este distrito, será construída a barragem. As comunidades tradicionais que habitam a jusante da barragem foram todas excluídas. O laudo do MPF informou, entretanto, que existem no local aproximadamente 61 comunidades tradicionais (FERREIRA, 2017).

É sabido que a população tradicional e os povos indígenas da Amazônia são totalmente dependentes da terra, da floresta e dos rios para sua subsistência. Se a inter-relação entre os três meios (físico, biótico e socioeconômico) não for objeto de análise no EIA, não explorando dados referentes ao modo de vida da população, potencialmente atingida, principalmente em relação a sua dependência com os recursos hídricos, ao regime de cheias e vazantes, aos recursos da fauna e da flora acessados pelos habitantes, as conclusões dos estudos não refletirão a realidade local, principalmente do ponto de vista da análise socioeconômica das regiões impactadas, resultando na exclusão de grupos e famílias das medidas e programas de reparação de danos.

Destaca-se que os efeitos prejudiciais, a jusante do barramento, somente serão sentidos após o enchimento do reservatório, algum tempo depois das obras da construção da barragem. Exemplo deste impacto tardio pôde ser verificado na fase de operação das usinas do Complexo do Madeira, em que as áreas à jusante das barragens só começaram a registrar impactos após a construção do empreendimento (COSTA SILVA, 2018; ARAÚJO \& MORET, 2016).

Nesta toada, é possível afirmar que as comunidades à jusante da barragem de Tabajara, provavelmente, também sentirão forte impacto decorrente das atividades das usinas, algum período depois da fase da construção, principalmente na atividade pesqueira, com restrições e perdas de espécies, em razão da mudança ao regime hídrico do rio Machado. Não somente o rio será afetado, mas as áreas de florestas também sofrerão influência decorrente da elevação do lençol freático (encharcamento do solo), produzindo também perda ou redução dos recursos da agricultura. Atingidas, possivelmente, também serão as áreas utilizadas para o plantio em várzeas, visto que 
estas áreas, comumente usadas no plantio sazonal, poderão ser totalmente suprimidas.

Assim sendo, não se pode perder de vista que, não raras vezes, os EIA's produzidos pelas empresas de consultoria do país utilizam métodos que favorecem os consórcios, negligenciando impactos sociais, e que eles são elaborados para viabilizar a aprovação do projeto, mesmo que os impactos sejam graves, com imenso poder de destruição dos locais apropriados.

\section{Direitos Humanos e modos de vida em Tabajara}

Em virtude das características da colonização agrícola na região de instalação da UHE Tabajara, o local evoluiu dando origem às várias reservas extrativistas projetos de assentamento - florestas estaduais, as quais abrigam diversas famílias que desenvolvem atividades de modo tradicional. Trata-se de um região de Rondônia, permeada pelo rio Machado (ou Ji-Paraná), que no início do século XX apresentou grande importância econômica em função da extração da borracha, formando comunidades que há décadas povoaram essa parte da Amazônia (FONSECA, 2007).

$\mathrm{Na}$ década de 1980, em função do acelerado processo de migração regional, de uma região distante das dinâmicas socioeconômicas da colonização agrícola, a cidade de Machadinho D'Oeste e a região de Tabajara aos poucos foram permeadas pelos ventos da agropecuária e da extração madeireira, o que levou o Governo de Rondônia a instituir uma ampla área de proteção da natureza e dos povos tradicionais, o que resultou na instituição de novas Unidades de Conservação (Mapa 2).

Desse modo, na região de influência da UHE Tabajara há no total 61 comunidades tradicionais que poderão ser impactadas pela hidrelétrica, distribuídas em quatro municípios (Machadinho do Oeste, em Rondônia; Manicoré, Humaitá e Nova Aripuanã, no Amazonas) (FERREIRA, 2007). Nessa região, hoje, além da extração de látex para produção de borracha e da pesca, também se pratica a agricultura de subsistência. Em geral, a produção dos povos e comunidades tradicionais (plantio, criação, caça, pesca, extrativismo, artesanato, etc.) está diretamente relacionada com as relações de parentesco, baseadas na solidariedade entre as famílias. Parte considerável da produção é destinada ao próprio consumo. 
Tais atividades são muito importantes não só para o desenvolvimento econômico, mas também para o desenvolvimento social e cultural destes grupos.

Os povos tradicionais da Amazônia, em especial, da região de Tabajara, têm a marcante característica de possuir famílias extensas ou ampliadas, atendendo às necessidades sociais, culturais e econômicas destes grupos. Para estas comunidades, sabe-se que a organização familiar é central para o funcionamento da comunidade e sua relação com o território. Em linhas gerais, o processo de construção identitária de uma comunidade tradicional decorre de um processo complexo: "a terra e o rio não significam apenas uma dimensão física, antes de tudo é um espaço comum, ancestral, de todos que tem registro na história, da experiência pessoal e coletiva" ( FERREIRA, 2017, p.19). Assim sendo, para estes povos, os rios consistem em um "ponto de reunião entre as pessoas, local de diversas atividades como: viver, cultivar, divertir/lazer, pescar, trabalhar no comércio e muitas outras possibilidades" (FERREIRA, 2017, p. 119). Logo, rio é um lugar que "reúne vários grupos e isso favorece diversas atividades econômicas locais" (FERREIRA, 2017, p. 19).

No caso concreto, as entrevistas realizadas pela Perita do MPF, e nos trabalhos de campo para observação direta do quadro geral das condições socioeconômicas das comunidades rurais de Tabajara, indicaram que as comunidades tradicionais da região desenvolvem atividades baseadas em conhecimentos tradicionais acumulados por gerações: a pesca é feita nos rios e lagos da região, inclusive em igarapés; quanto à caça, porco do mato, paca e cutia são as espécies mais frequentemente abatidas; os moradores das comunidades também criam algumas cabeças de gado, visando a retirada de leite para consumo próprio, além da criação de aves; a agricultura é voltada para subsistência familiar, com a venda de alguns itens excedentes: mandioca, milho, arroz de sequeiro, banana, café, feijão abóbora, melancia e amendoim, registrando-se que estes cultivos são feitos nas áreas próximas das casas. Algumas famílias também produzem farinha, extraída da mandioca cultivada; por sua vez, o extrativismo vegetal na região, igualmente, consiste em uma atividade tradicional muito difundida e baseia-se, além da extração da própria borracha, na coleta de produtos da floresta, tais como, a castanha do Brasil, açaí e copaíba. Tais produtos são utilizados, além do consumo próprio, para fins medicinais (FERREIRA, 2017). 
A pesca tradicional também é uma das atividades econômicas preferidas das famílias, pois fornece renda, além de alimentar seus membros (FERREIRA, 2017; CUNHA \& COSTA SILVA, 2019). A pesca artesanal "realizada em comunidade ribeirinha na Amazônia emprega cinco vezes mais pescadores e tem uma produção anual de cerca de 2,5 vezes maior que a pesca desembarcada no mercado público" (FERREIRA, 2017, p. 127). Os pescadores artesanais desenvolvem técnicas sustentáveis de captura de baixo impacto sobre a ictiofauna, e trabalham sozinhos e/ou utilizam mão de obra familiar ou não assalariada. A atividade envolve uma diversidade de modalidade de técnicas, modos de apropriação de recursos pesqueiros, formas de organização de produção e distribuição dos rendimentos, ligados a formas especiais de organização social (FERREIRA, 2017, p. 127 e 128). Ao longo de, pelo menos, um século "aquelas comunidades garantem os seus terrenos de cultivo e continuidade de suas atividades econômicas indispensáveis à sua reprodução física e social" (FERREIRA, 2017, p. 132).

Assim sendo, percebe-se o quanto é importante a manutenção do equilíbrio do ecossistema da região do rio Machado. Alterações antrópicas no meio ambiente certamente impactarão os territórios destas comunidades que lá habitam por mais de um século. Caso o regime hídrico do rio seja modificado e afete a quantidade e a qualidade dos peixes, provavelmente os pescadores amargarão prejuízos de toda ordem, inclusive com ameaça da própria subsistência da família. Do mesmo modo, caso as florestas sejam impactadas pelo empreendimento, em razão, por exemplo, do encharcamento do solo causado pela elevação do lençol freático, a atividade extrativista poderá restar comprometida, o mesmo se podendo concluir acerca da inviabilidade do plantio dos gêneros alimentícios de necessidade própria da família, em razão da imprestabilidade do solo exageradamente úmido.

Tais impactos precisam, necessariamente, ser corretamente identificados e avaliados nos estudos ambientais, como se faz indispensável produzir dados e informações verídicas a respeito de todos os indivíduos e grupos que poderão sofrer as consequências das alterações adversas causadas no meio ambiente, sendo que a exclusão de alguns grupos dos programas e reparações devidas, poderá comprometer a sobrevivência destas pessoas excluídas.

Por essas razões, constata-se o quanto é relevante a abordagem adequada do conceito de atingido e de reconhecimento da tradicionalidade destas comunidades, 
visto que estas qualificações servem de base para a incidência de uma série de direitos fundamentais afetos a estes povos (FONSECA, 2007; ARAÚJO \& MORET, 2016; FERREIRA, 2017; CUNHA \& COSTA SILVA, 2019). Logo, toda atenção é devida por parte das instituições de fiscalização e controle de violações a direitos fundamentais de minorias atingidas por grandes empreendimentos econômicos.

Entende-se que um estudo aprofundado do componente tradicional (ribeirinho, pesqueiro e extrativista), semelhante ao que existe para a temática indígena, deve ser exigido do consórcio realizador da obra. Somente com a elaboração de um estudo específico do componente tradicional, os impactos socioambientais destes povos da região poderão ser adequadamente identificados, avaliados, mitigados e/ou compensados de forma integral e justa.

Os grupos tradicionais de ribeirinhos, extrativistas e pescadores merecem um estudo próprio em razão das especificidades incomuns destes povos, que os fazem ser diferenciados culturalmente. Registra-se que o EIA não teceu uma linha sequer sobre a tradicionalidade destes povos. Apenas foram feitas considerações de que as atividades das pessoas possivelmente atingidas pelo empreendimento seriam "rudimentares" (FERREIRA, 2017).

Neste mesmo sentido, o laudo do MPF concluiu pela necessidade de realização de um estudo, em separado, do Componente Pesqueiro, além do Componente Tradicional (ribeirinho e extrativista), em analogia ao Estudo do Componente Indígena, vez que muitas famílias de pescadores localizam-se próximas à área da barragem e da alagação, e não foram incluídas nos dados produzidos pelos cadastradores contratados pelo empreendedor. Logo, "a invisibilidade dos tradicionais somada ao monitoramento inadequado pode colocar em risco a continuidade destas comunidades, tal como ocorreu com os Pescadores Tradicionais de Abunã, no licenciamento da UHE Jirau e Santo Antônio" (FERREIRA, 2017, p. 182).

Dado o quadro geral dos processos socioeconômicos e territoriais postos, pode-se afirmar é que os impactos na cidade tendem a ser "positivamente" diluídos na medida em que há um crescimento da economia urbana, principalmente nos setores de serviços e comércio, em que a taxa de empregabilidade e geração de renda aumentam consideravelmente. Todavia, no mundo agrário onde estão territorializadas as comunidades rurais, as quais são diretamente apontadas como "potencial público alvo" dos deslocamentos compulsórios indicados nos estudos de impacto ambiental 

aprofundar as pressões econômicas nos territórios tradicionais e nas posses das pequenas propriedades familiares, pois, como verificado qualitativamente em trabalho de campo, o preço da terra agrícola/área de pastagem aumenta no mercado local, e as invertidas contra os territórios tradicionais e os espaços coletivos de trabalho (a exemplo do rio Machado, onde os pescadores ainda podem desenvolver suas atividade laborais) convergem à expropriação desses grupos sociais, atingindo seus direitos sociais básicos.

\section{Considerações finais}

A expansão dos projetos energéticos na região amazônica tem gerado um passivo social impagável, além de impactos ambientais de proporções estratosféricas, em geral, atingindo os territórios das comunidades tradicionais e povos indígenas, sem qualquer alteração nas políticas públicas de equacionamentos de danos socioambientais da região.

Os EIA/RIMA's apresentados pelos empreendimentos hidrelétricos da região Norte, para subsidiar o processo de decisão sobre a viabilidade ambiental dos projetos são frequentemente insuficientes, subestimados e pouco analíticos. Tais estudos deficientes acabam por se transmudar em um veículo legitimador da aprovação de projetos impactantes e devastadores, sob o ponto de vista dos Direitos Humanos dos grupos sociais atingidos. No caso específico do Projeto Hidrelétrico Tabajara, o laudo pericial do MPF/RO (FERREIRA, 2017) sinalizou que, muito provavelmente, os impactos atingirão muitas comunidades tradicionais (pescadores, ribeirinhos, extrativistas, etc) e diversos povos indígenas, entre eles, dois grupos de índios isolados. Tais comunidades habitantes do local não foram sequer mencionadas no EIA, numa franca tentativa de reduzir, ao máximo, os custos sociais da obra. Ao término deste texto, o Instituto Brasileiro do Meio Ambiente e dos Recursos Naturais Renováveis - IBAMA emitiu parecer acatando parte das recomendações do MPF/RO para que o EIA/RIMA sofresse alterações, sobretudo, com vistas a mensurar e dimensionar melhor os possíveis impactos nas comunidades tradicionais da região.

De modo geral, conclui-se que os grandes projetos na Amazônia e, 
particularmente, as hidrelétricas, instituem escalas de domínio político de recursos naturais e territórios, de modo que se ressalta o uso corporativo do espaço regional na escala do capital e do Estado, ao passo que, igualmente, tem-se a alienação dos territórios dos grupos sociais mais vulneráveis, no qual o sentido e destino do lugar ficam afetados pelas lógicas do capital hidrelétrico, o que se constitui também em formas de dominação e expropriação social.

\section{Referências}

ALMEIDA, A. W. B. de (Org.) Conflitos sociais no complexo Madeira. Manaus: UEA, 2009.

ARAUJO, N. C.; MORET, A. D. S. Direitos Humanos e Hidrelétricas: uma análise dos impactos socioambientais e econômicos gerados em Rondônia. Veredas do Direito, Belo Horizonte, v.13, n.26, p.167-194, Maio/Agosto de 2016. Disponível em: $<$ http://revista.domhelder.edu.br/index.php/veredas/article/view/622> Acessado em 15 de novembro de 2020.

BOTTOMORE, T. Dicionário do pensamento marxista. Rio de Janeiro: Jorge Zahar Ed., 2001.

BRASIL. Eletronorte. Aproveitamento Hidrelétrico de Tabajara. Dezembro de 2019, 9. v. Disponível em: <http://licenciamento.ibama.gov.br/Hidreletricas/Tabajara/> Acessado em 28 de maio de 2020.

BRASIL. ELETRONORTE. Memória Técnica - UHE Samuel. Brasília, ELETRONORTE, 1996. Link: http://agencia.eletronorte.gov.br/site/eletronorte/wpcontent/uploads/sites/101/2020/04/UHE-Samuel-Mem\%C3\%B3ria-

\section{T\%C3\%A9cnica.pdf}

BRASIL. Instituto Brasileiro do Meio Ambiente e dos Recursos Naturais Renováveis IBAMA. Parecer Técnico no 110/2020-COHID/CGTEF/DILIC, AHE TABAJARA. Brasília, 20 de agosto de 2020.

CASTILHO, D. Hidrelétricas na Amazônia brasileira: da expansão à espoliação. In: $V$ Simpósio Internacional de História da Eletrificação, 2019, Évora (Portugal). Eletricidade e a transformação da vida urbana e social. Évora: CIDEHUS, 2019. p. 1 20. Disponível em: <http://www.ub.edu/geocrit/Electricidad-y-transformacion-de-lavida-urbana/DenisCastilho.pdf> Acessado em 27 de maio de 2020.

CASTRO, E. Expansão da fronteira, megaprojetos de infraestrutura e integração sulamericana. CADERNO CRH, Salvador, v. 25, n. 64, p. 45-61, Jan./Abr. 2012. Disponível em: <http://dx.doi.org/10.1590/S0103-49792012000100004> Acessado em 27 de maio de 2020.

CAVAlCANTE, M. M.; NUNES, D. D; COSTA SILVA, R. G.; LOBATO, L. C. H. Políticas Territoriais e Mobilidade Populacional na Amazônia: contribuições sobre a área de influência das Hidrelétricas no Rio Madeira (Rondônia/Brasil). Confins (Paris), p. 1-18, 2011. Disponível em: <https://journals.openedition.org/confins/6924> Acessado em 28 de maio de 2020. 
CDPH. Conselho de Defesa dos Direitos da Pessoa Humana. Relatório da comissão especial dos atingidos por barragens. Brasília, 2010. Disponível em: $<$ http://pfdc.pgr.mpf.mp.br/temas-de-atuacao/populacao-atingida-pelas-

barragens/atuacao-do-mpf/relatorio-final-cddph>. Acessado em 24 de agosto de 2019.

COSTA SILVA, R. G. (Org.) Porto Velho Cultura, Natureza e Território. 1. ed. Porto Velho: Edufro/Temática Editora, 2018. v. 1. p. 266. Impresso. Link: http://www.gtga.unir.br/pagina/exibir/9501

COSTA SILVA, R. G.; LIMA, L. A. P; CONCEIÇÃO, F. S. Territórios em disputas na Amazônia brasileira: ribeirinhos e camponeses frente as hidrelétricas e ao agronegócio. Confins (Paris), v. 36, p. 1-12, 2018. Disponível em: $<$ https://journals.openedition.org/confins/13980>. Acessado em 27 de maio de 2020.

COSTA SILVA, R. G; SILVA, V. V; LIMA, L. A. P. Os novos eixos da fronteira na Amazônia ocidental. CONFINS (PARIS), v. 43, p. 1-6, 2019. Link:

https://journals.openedition.org/confins/24950

CUNHA, G. D. O. B.; COSTA SILVA, R. G. Invisibilidades produzidas: o "desaparecimento" das comunidades ribeirinhas nos estudos da hidrelétrica Tabajara (Amazônia brasileira). REVISTA INTERDISCIPLINAR DE DIREITOS HUMANOS, v. 7, p. $\quad 95-116, \quad 2019 . \quad$ Link: https://www3.faac.unesp.br/ridh/index.php/ridh/article/view/713

DIÁRIO DA AMAZÔNIA. Anúncio de hidrelétrica já aumenta procura de casas em Machadinho. Jornal Diário da Amazônia, 29/10/2019. Link: https://www.diariodaamazonia.com.br/anuncio-de-hidreletrica-ja-aumenta-procurade-casas-em-machadinho/

ESTADÃO. Eletronorte apresenta novo estudo ambiental para erguer usina na Amazônia. Seção Economia, Jornal Estadão, 18 de dezembro de 2019. Disponível em: $\quad<$ https://economia.estadao.com.br/noticias/geral,eletronorte-apresenta-novoestudo-ambiental-para-erguer-usina-na-amazonia,70003129520> Acessado em 28 de maio de 2020.

FEARNSIDE, P. M. (org.). Hidrelétricas na Amazônia: Impactos Ambientais e Sociais na Tomada de Decisões sobre Grandes Obras. Manaus: Editora do INPA, v. 2, 2015.

FEARNSIDE, Philip M. A hidrelétrica de Samuel: Lições para as políticas de desenvolvimento energética e ambiental na Amazônia. Instituto Nacional de Pesquisas da Amazônia (INPA). Manaus: 2004.

FGV, Fundação Getúlio Vargas. Grandes obras na Amazônia: aprendizados e diretrizes. São Paulo, 2017. 259 p. Disponível em: http://www.gvces.com.br/grandesobras-na-amazonia-aprendizados-e-diretrizes?locale=pt-br. Acesso em: 05. Nov. 2019.

FERREIRA, R. C. Usina Hidrelétrica de Tabajara, Machadinho Do Oeste/RO. Laudo Pericial 02/2017/SPJPR, Secretaria de Perícia, Pesquisa e Análise (SPPEA); Procuradoria Geral da República, Brasília: MPF, 2017.

FONSECA, Dante Ribeiro. Estudos de História da Amazônia. 1. ed. Porto Velho: Maia, 2007. v. 1. 260p.

FRANCO, T. Alienação do trabalho: despertencimento social e desrenraizamento em 
relação à natureza. Caderno $C R H$, Salvador, v. 24, n. 1, p. 171-191, 2011.

GOTTMANN, J. The evolution of the concept of territory. Social Science Information, v. 14, n. 3, ago. 1975, p. 29-47.

HAESBAERT, R. O mito da desterritorialização: Do "fim dos territórios" à multiterritorialidade. Rio de Janeiro: Bertrand Brasil, 2004.

IBGE. Portal Cidades e Estados, 2020. Disponível em: <https://www.ibge.gov.br/cidades-e-estados/ro/machadinho-doeste.html>. Acessado em 28 de maio de 2020.

IORIS, A. A. R. Da foz às nascentes: análise histórica e apropriação econômica dos recursos hídricos no Brasil. In. Capitalismo globalizado e recursos territoriais. Ed. Lamparina, Rio de Janeiro, 2010. p. 211-256.

KRENAK, A. Ideias para Adiar o Fim do Mundo. 1 ed., São Paulo: Companhia das Letras, 2019.

LIMA, L. A. P. Território e os efeitos da antecipação temporal na Amazônia: pescadores e a instalação de UHE em Apuí (AM) e Colniza (MT) no rio Aripuanã. 2020. 317 f. Tese (Doutorado em Geografia), Universidade Federal de Rondônia UNIR, Porto Velho, 2020.

LIMA, L. A. P; COSTA SILVA, R. G. Cartografia das hidroestratégias na Amazônia brasileira. ACTA GEOGRAFICA, v. 12, p. 129-142, 2018. Disponível em: $<$ https://revista.ufrr.br/actageo/article/view/4510> Acessado em 28 de maio de 2020.

LIMA, L. A. P; COSTA SILVA, R. G. Pescadores, hidroelétricas e novos ordenamentos territoriais dos rios amazônicos. TERR@ PLURAL (UEPG. ONLINE), v. 13, p. 361374, $2019 . \quad$ Disponível em: <https://revistas.apps.uepg.br/index.php/tp/article/view/10876/artigo\%205> Acessado em 28 de maio de 2020.

MAB. Movimento dos Atingidos por Barragens. Ditadura contra as populações atingidas por barragens aumenta a pobreza do povo brasileiro. Brasília, 2004. Disponível em: https://www.alainet.org/pt/active/5807. Acesso em: 24. Ago. 2019.

MARX, Karl. Manuscritos económico-filosóficos. Tradução Artur Morão. Lisboa: Edições 70, 1993.

MÉSZÁROS, I. A teoria da alienação em Marx. São Paulo: Boitempo editorial, 2006.

PORTO-GONÇALVES, Carlos Walter. Amazônia: encruzilhada civilizatória: tensões territoriais em curso. Rio de Janeiro (RJ): Consequência, 2017.

PÚBLICA. Amazônia sem lei: O "maior desmatador do Brasil" possui 120 madeireiras na região Norte. Reportagem especial. Agência Pública, 22 de novembro de 2019. Disponível em: <https://apublica.org/2019/11/o-maior-desmatador-do-brasil-possui120-madeireiras-na-regiao-norte/> Acessado em 27 de maio de 2020.

RIBEIRO, A. C. T. Outros territórios, outros mapas. OSAL: Observatorio Social de América Latina, Ano 6, n. 16 (jun. 2005), Buenos Aires: CLACSO, 2005.

SANTOS, M. A natureza do espaço: técnica e tempo, razão e emoção. São Paulo: Editora Hucitec, 1996.

SANTOS, M. Por uma outra globalização: do pensamento único à consciência 
universal. Rio de Janeiro: Record, 2000.

SANTOS, M; SILVEIRA, M. L. O Brasil: território e sociedade no início do século XXI. Rio de Janeiro/São Paulo: Record, 2001.

SCABIN, F. S; PEDROSO-JUNIOR, N. N; CRUZ, J. C. C. Judicialização de grandes empreendimentos no Brasil: impactos da instalação de usinas hidrelétricas sobre comunidades locais na Amazônia. Revista Pós Ciências Sociais (REPOCS) - Dossiê Sociedade Ambiente e Governança, n. 22, 2015.

SEVÁ FILHO, Arsênio Oswaldo. Estranhas catedrais. Notas sobre o capital hidrelétrico, a Natureza e a Sociedade. Revista Ciência e Cultura. Núcleo Temático Energia, Ambiente e Sociedade, Vol. 60 № 3 São Paulo, Setembro de 2008.

VAINER, C. B. Os desafios da fragmentação. R.B. Estudos Urbanos e Regionais, v.9. n.1, maio, 2007.

WERNER, D. Desenvolvimento Regional e Grandes Projetos Hidrelétricos (19902010): o caso Complexo Madeira. Inc. Soc. v. 6, no 1. jul/dez. 2012. Brasília-DF. p.157-174. 